


\section{El origen del 'sueño' de la arquitectura de cristal. Una aproximación ${ }^{(1)}$ The 'Dream' of Crystal Architecture Origins. An Approach (1)}

\section{Rosana Rubio Hernández}

Facultad de Tecnología y Ciencia, Universidad Camilo José Cela, Madrid.

Traducción Translation Jamie Benyei

\section{Palabras clave Keywords}

Arquitectura, cristal, vidrio, luz, sol, divinidad, literatura medieval, textos sagrados, anagogía

Architecture, crystal, glass, light, sun, divinity, medieval literature, sacred texts, anagogy

\section{Resumen}

La historia de la arquitectura de vidrio se ha visto animada por un 'sueño' estimulado por las particulares propiedades de interacción de este material con la luz. El artículo se aproxima a la génesis de ese sueño y sus primeras manifestaciones, en forma de leyendas sobre fantásticos edificios de cristal transcritas en textos sagrados o literarios, y hace referencia a las arquitecturas en las que se ha materializado y a algunos de los arquitectos a los que ha inspirado. Se concluye que la pervivencia en el tiempo de este sueño, se debe a la capacidad otorgada al vidrio como vía para acceder indistintamente a 'anagogías' (elevación y enajenación del alma por la contemplación de las cosas 'divinas') de carácter religioso o laico.

\section{Abstract}

The history of glass architecture has been animated by a 'dream', stimulated by the particular interaction properties of this material with light. The article approaches to the genesis of that dream and its first manifestations, in the form of legends about fantastic glass buildings, transcribed in sacred or literary texts. It refers also to the architectures in which it has been materialized and some of the architects it has inspired. We conclude that the survival of this dream in time is due to the capacity granted to glass as a way to access indistinctly to 'anagogies' (elevation and alienation of the soul by the contemplation of 'divine' things), whether religious or secular. 
La arquitectura moderna y contemporánea hace un uso creciente del vidrio, al tiempo que la tecnología ha ido permitiendo mayores fantasías y libertades formales. Para entender el poder de seducción de este material debemos remontarnos en el tiempo. El vidrio, por su comportamiento ante la luz, a la que parece 'capturar', estuvo siempre ligado a lo mítico, a lo mágico, al misterio; temas todos difíciles de confinar en el ámbito estrictamente científico. (2) Este material ha provocado en el imaginario colectivo occidental, la ilusión ser aquel a través del cual poder acceder a una anagogía (elevación y enajenación del alma por la contemplación de las cosas divinas), dando lugar a lo que hemos llamado el 'sueño de la arquitectura de cristal'. Un sueño que surge hace más de tres mil años en el Mediterráneo oriental y que pensamos que prevalece.

Las propiedades, únicas en la naturaleza, de color, transparencia y reflectancia de algunos materiales y también del vidrio hecho por el hombre, que trataba de imitarlos, han asociado a este material artificial con los valores más estimados de las piedras preciosas. Esas piedras preciosas, presentes siempre en los ajuares de las monarquías teocráticas de la antigüedad, por su rareza, belleza y escasez, representaban de alguna forma la legitimidad del mandato de quienes las portaban. Por otra parte, el culto solar, siempre presente en aquellas culturas, posibilitaba establecer una relación natural entre el dios-sol y aquellos objetos, que brillaban como él. El sol es calor, luz y fuente de vida, como lo es el fuego. Casi todas las mitologías hablan del hallazgo y dominio del fuego, y quienes lo dominan son héroes, dioses o semidioses; al fuego, precisamente, está ligado el origen del vidrio.

La génesis del vidrio artificial, según conjeturan muchos estudiosos, surge del fructífero encuentro en el seno de las culturas mesopotámicas, entre los artesanos metalúrgicos hurritas, maestros dominadores del fuego y los alfareros asentados en el este de la Media Luna Fértil; es decir, con la combinación de dos tecnologías que consiguieron emular las fuerzas y procesos de la naturaleza: la metalúrgica y la alfarera. (3) Así, las sociedades mesopotá-

The use of glass in modern and contemporary architecture is increasing and technology now facilitates greater fantasies and freer forms. To understand the seductive power of this material, we must go back in time. The behaviour of glass in the presence of light, which it seems to 'capture', has always been associated with mythology, magic and mystery, all difficult to confine to the strict realm of science. (2) In the Western imagination, glass has conjured up the dream of being a gateway to an anagogy (the elevation and alienation of the soul through the contemplation of divine things), leading to what we call the dream of crystal architecture, a dream that began more than 3000 years ago in the Eastern Mediterranean and, we believe, is still prevalent today.

The unique colour, transparency and reflective properties of natural substances and also certain artificial materials like glass - produced by people who strove to replicate them - led this man-made 'crystal' to be associated with the most highly appreciated values of precious stones. These stones, ever-present in the trousseaux of ancient theocratic monarchs on account of their scarcity and beauty, symbolised the legitimacy of the owner's mandate. Sun worship, also pervasive in these cultures, provided a natural link between the solar deities and the objects that shone like them. The sun is heat, light and a source of life, like fire. The discovery and control of fire is mentioned in most ancient mythologies, and those who possessed this knowledge were heroes, gods or demigods. And in turn, fire is linked to the source of glass.

Many historians believe that the origins of manufactured glass can be traced back to the fortuitous encounter in Mesopotamia between Hurrite metal craftsmen, masters of fire, and potters who lived in the eastern zone of the 
mica y egipcia - dominadoras de la tecnología del vidrio y con importantes cursos fluviales a lo largo de los que se desarrollaron sus centros urbanos y que reflejaban, al igual que lo hacía el vidrio, aquello a lo que adoraban, el sol- crearon una mítica en la que éste, divinidad y fuente de vida, se asociaba con el agua y con el vidrio.

En el siglo XIV a. C., en Egipto, hace su aparición el primero de los mitos en que se relaciona al vidrio con la divinidad. El faraón Amenhotep IV había instaurado el culto de Atón, el sol, cambiando su propio nombre por el de Akenatón (resplandor de Atón) y fundando una nueva capital en el 1366 a. C., a la que llamó Aketatón (horizonte de Atón); una ciudad pura, desligada de los cultos anteriores. Cuenta alguna leyenda que su palacio estaba pavimentado con vidrio dispuesto sobre agua corriente. Esta leyenda puede estar relacionada con lo que nos narra el egiptólogo Jacques Pirenne en la descripción de los palacios de Aketatón, a partir de los datos arqueológicos disponibles: "[...] En el suelo, una serie de estanques [...] tenían los bordes inclinados y sobre ellos se habían pintado en vivos colores, nenúfares y lotos que parecían salir del agua. [...] Desde este pórtico hasta un pequeño templo se extendía un jardín [...] donde el agua tenía un papel preponderante". (4) Los bordes de los estanques del palacio se revestían de piezas de fayenza silícea, pintada con representaciones de escenas acuáticas; su acabado vítreo brillante, junto con el agua representada en ellas, bien pudieron dar lugar al mito de un suelo de vidrio dispuesto sobre agua corriente. (Fig. 1) Lo cierto es que el reinado de Akenatón coincidió con una etapa de esplendor de la industria del vidrio en Egipto, habiéndose encontrado restos de una importante factoría en las ruinas de Aketatón, cerca de Tell-el-Amarna. (5)

La primera referencia escrita a un mar de vidrio frente al trono de un dios aparece en el siglo I, ya dentro del contexto judeo-cristiano, en el Apocalipsis atribuido al apóstol Juan: "Delante del trono arden siete antorchas de fuego $[\ldots]$ y hay una especie de mar transparente semejante al cristal". (6) Algo después, la historia del suelo de cristal aparece en Israel, liga-

Fertile Crescent, in other words, the combination of two technologies that emulated the forces and processes of nature: metallurgy and pottery. (3) Mesopotamian and Egyptian societies, with their dominion of glass technology and control of major rivers, built their cities along these watercourses as a reflection, like glass, of their object of adoration, the sun. They shaped legends that linked this divinity and source of life to water and glass.

The first such myth that connected gods to glass first appeared in 14th Century B.C. Egypt, under the reign of Amenhotep Iv. This Pharaoh, responsible for the worship of Aton, the sun, changed his own name to Akhenaten (the radiance of Aton) and founded a new capital in 1366 B.C., Aketaton (Aton's horizon), a pure city, disconnected from previous cults. Legend has it that his palace was paved with glass laid above running water. This legend could be related to Egyptologist Jacques Pirenne's description of the palaces in Aketaton, based on archaeological information: "[...] On the ground, a series of ponds [...] with sloping edges decorated in vivid colours with water lilies and lotuses that seemed to emerge from the water. [...] Between this gateway and a small temple there was a garden [...] in which water also played a predominant role". (4) Silica faience tiles were laid around the edges of the palace ponds, painted with representations of water scenes. Their glossy vitreous finish and the water depicted in them may well have been the source of the myth of a glass floor laid over running water. (Fig. 1) It is certainly true that Akhenaten's reign coincided with a period of splendour for Egypt's glass industry. Remains of a large factory have been found in the ruins of Akhenaten, near Tell-el-Amarna. (5) 


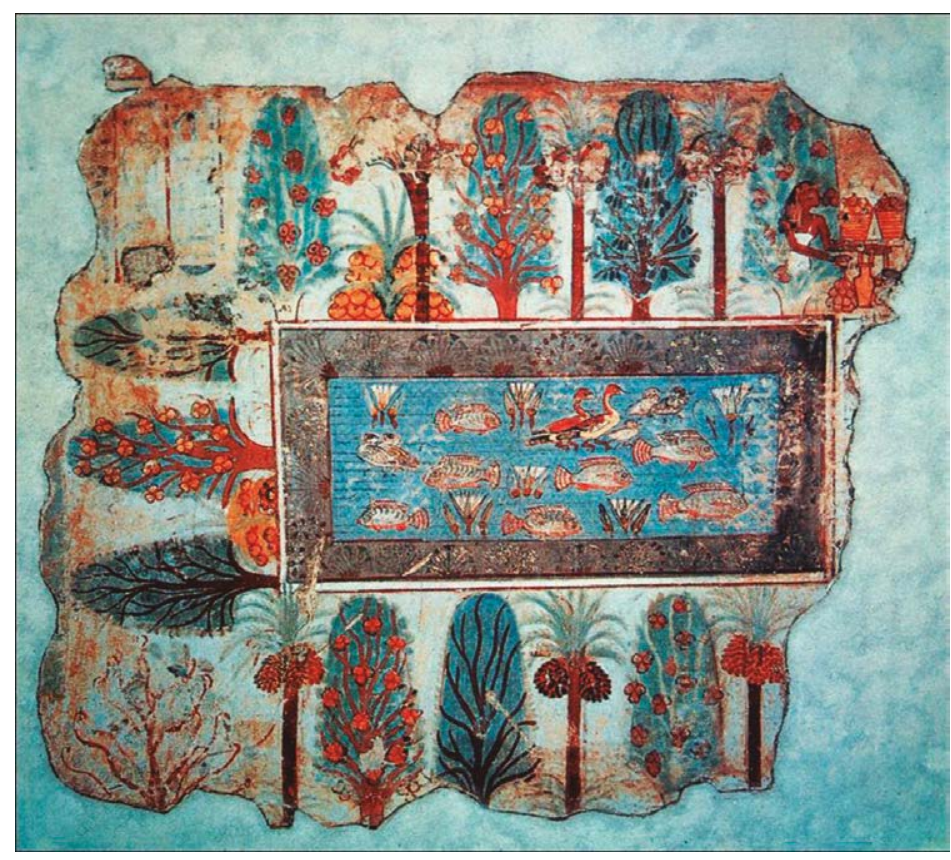

da al rey Salomón, en el Targum Shenī, cuya fecha de redacción, aunque incierta, puede estar en torno al siglo vir. En él podemos leer: "Después de tres años, la reina de Saba llegó al reino de Salomón [...] Benaiah la condujo al rey, quien, cuando oyó que venía, se sentó en su habitación de cristal. Cuando la reina vio al rey sentado allí pensó de corazón que estaba sentado en agua y de hecho así lo dijo. Y se levantó el vestido para cruzar el agua, con lo que el rey se dio cuenta de que su pie era peludo. Le dijo, 'Tu belleza es belleza de mujer y tu pelo es pelo de hombre; el pelo resulta atractivo en un hombre, pero en una mujer es vergonzoso'”. (7) Aquí, la referencia a la arquitectura de vidrio y la sugerencia de asemejarse a
Fig. 1. Estanque en un jardín. Fragmento de un fresco de la tumba de Nebamun, c.1350 a.C.

The first written reference to a sea of glass before the throne of a god is from the 1st Century A.D., in the Revelation attributed to St. John: "In front of the throne were seven torches of burning fire [...] and also there was something like a sea of glass, like crystal" (6) Some time later, the story of the glass floor reappeared in Israel, in the Targum Shenī, thought to date from around the 6th Century A.D., linked to King Solomon: "At the end of three years, the Queen of Sheba came to the kingdom of Solomon [...] She was conducted by Benaiah to Jerusalem, and when the King was told that the Queen of Sheba had just arrived, he went to sit in his glass pavilion. When she saw the king sitting in his glass pavilion, she thought within herself that the King sat upon water, and so proceeded to draw up the hem of her dress so that she could pass over without getting wet. The King saw her legs full of hair. He said, 'Thy beauty is the beauty befitting women, but thy hairs are the hairs befitting men. Hair on a man's body is comely, but uncomely on a woman's'”. (7) In this legend, the reference to glass architecture and the resemblance of reflective waters is quite straightforward. Moreover, in this case, glass is endowed with the ability to 'reveal' something which would otherwise remain hidden: the true nature of the Queen. In this same century, Muslim tradition picked up the same story, repeated in the Qur'an, with a variation. (8) Sura 27 recites: "It was said to her, 'Go inside the palace'. And when she saw it, she thought it was a deep pond, and she bared her legs. He said, 'It is a palace paved with glass' She said, 'My Lord, I have done wrong to myself, and I have submitted with Solomon, to God, Lord of the Worlds'”. (9)

It would be nice to think that all these legends have a common mythical origin, the purported relationship between the Jewish and Egyptian people at the time of Dynasty xix, described in the Bible, when memories of Pharaoh 
aguas reflectantes es bastante directa; además vemos cómo se le confiere al material la capacidad de 'revelar' lo que de otro modo permanecería oculto: es decir, la verdadera naturaleza de la Reina. En este mismo siglo, la tradición musulmana recoge el mismo relato en el Corán, con alguna variante. (8) En la sura 27 puede leerse: “Se le dijo: '¡Entra en el palacio!' Cuando lo vio, creyó que era un estanque y puso sus piernas al descubierto. Salomón dijo: 'Es un palacio enlosado de cristal'. Ella exclamó: '¡Señor mío! He sido injusta conmigo. Con Salomón, yo me someto a Dios, Señor de los mundos'”. (9)

Resulta atractivo pensar que todas estas leyendas pueden tener un origen mítico común, en la supuesta relación del pueblo judío con el egipcio, tal como es narrada en la Biblia, en tiempos de la xix Dinastía, estando aún reciente el recuerdo del faraón Akenatón. (10) En esa época pudo tener lugar, en el caso de haber sucedido, el éxodo del pueblo judío - narrado en el Éxodo, pero del que no hay ninguna prueba histórica ni arqueológica que lo constate - desde Egipto hasta Judea y con ellos, las leyendas sobre el palacio de Akenatón transmitidas y magnificadas oralmente de generación en generación. (11) En esa huida, el paso del Yam Suf (Mar Rojo) sería en realidad el paso del lago Menzala o el lago Sirbonis: "El agua poco profunda de este último permite atravesarlo a pie por varios puntos, y el que va por la angosta franja de terreno que separa la laguna del Mediterráneo se encuentra rodeado de agua". (12) De hecho, el trasiego de pueblos por ese paso entre Asia Menor y Egipto, cuando ambos continentes estaban unidos, se haría por esa zona y el recuerdo de grandes superficies de agua somera y espejeante, puede ser el origen de la imagen recurrente del "andar sobre las aguas" o "sobre un mar de cristal” en la literatura judía. (13)

Aunque en los relatos bíblicos no se menciona el vidrio propiamente dicho como material de construcción del Templo de Salomón, sí se habla del oro que revestía el Debir junto a la madera de cedro, (14) que unidos al vidrio en las versiones apócrifas constituirán en conjunto una simbología arquitectónica en torno al fenómeno de la luz, que se perpetuará a

Akhenaton were still fresh. (10) This was the time of the flight of the Jews from Egypt to Judea -if, indeed, it happened - narrated in Exodus, despite the lack of historical or archaeological proof. No doubt they took with them the legends of Akhenaton's palace, passed on from generation to generation and magnified through oral tradition. (11) The Yam Suf (Red Sea) passage used in their flight was actually a ford on Lake Menzala or Lake Sirbonis: "The shallow waters of the latter can be crossed on foot at several points, and he who traverses the narrow strip of land that separates the lagoon from the Mediterranean is surrounded by water" (12) The transit of peoples between Asia Minor and Egypt, at a time when the two continents were connected, probably took place across such a passage in this area. The origin of the recurrent image of "walking on water" or"over a sea of glass" found in Jewish literature may thus well be memories of large expanses of shallow, reflective water. (13)

Although biblical accounts do not specifically mention glass as a building material in King Solomon's temple, they do speak of gold cladding on the Debir, used in conjunction with cedar wood. (14) These materials, along with glass, appear in the Apocrypha as an architectural symbol for the phenomenon of light. In the course of the following centuries, they continued to inspire legends in different traditions, probably due to the projection of the king as an exemplary figure, the confluence of great power, both spiritual and material. In 537 A.D., on the day of the Hagia Sophia Cathedral's consecration, tradition has it that Justinian declared, "Solomon, I have beaten you". (15) True or not, these words do reflect the Emperor's legitimate pride in his magnificent achievement. They also reflect the ongoing potential of the above-mentioned "crystalline" traditions, condensed in the apocryphal descriptions 
lo largo de los siglos y que servirán de inspiración a leyendas posteriores en distintas tradiciones que se hacen eco de ello, probablemente por su presentación del Rey como figura ejemplar, al aunar grandes poderes tanto espirituales como materiales. En el año 537, según cuenta la tradición, el día de la consagración de Santa Sofía, dijo Justiniano: "Salomón, te he vencido". (15) Ciertas o no, esas palabras muestran el legítimo orgullo del emperador ante su magnífica obra; pero también ponen de manifiesto la vigencia de todas estas tradiciones "cristalinas" de las que venimos hablando, condensadas en las descripciones apócrifas del Templo de Salomón. Lo cierto es que Justiniano 'construye', no un suelo sino un cielo de vidrio de fondo de oro sobre su templo, dando así continuidad al sueño de la arquitectura de cristal, materializándolo por vez primera, de forma significativa: (Fig. 2) en Santa Sofía, los muros revestidos de vidrio se convierten en un elemento de transmisión del simbolismo de la luz capaz de 'iluminar' al hombre.

En la época en que la primera arquitectura bizantina está produciendo sus mayores logros, en los primeros siglos del cristianismo, la luz anagógica ocupa el pensamiento de los Padres de la Iglesia, influido por el neoplatonismo de autores como Plotino. Se escapa al cometido de este artículo ahondar en cómo se elaboró la 'estética de la luz' en el cristianismo a partir del pensamiento clásico, (16) pero nos parece oportuno, en el marco de nuestros objetivos, citar como testimonio un fragmento de un texto fundacional de la Patrística, Las confesiones de Agustín de Hipona, donde se alude al papel trascendente de la luz para alcanzar el conocimiento divino: “ $¿$ No es cierto que vuelven a Vos muchos $[\ldots]$ recibiendo aquella luz que a los que la reciben les da juntamente potestad para hacerse hijos vuestros?" (17)

Continuando con nuestra narración, en el 'Digenes Akrites', poema épico de finales del siglo Ix o principios del siglo $\mathrm{x}$, que tuvo gran éxito en $\mathrm{Bi}$ zancio desde el imperio medio volvemos a encontrar los suelos "de agua". "Pavimentó el suelo con ónice tan suavemente pulido, que aquellos que
Fig. 2. Dibujo de Santa Sofía. Fossati, Gaspare: Aya Sofia Constantinople, 1852

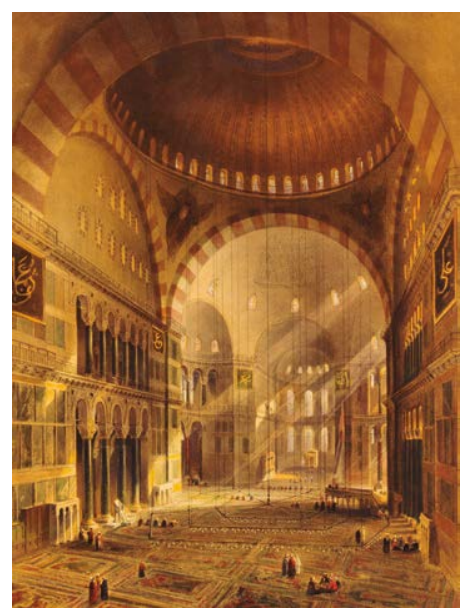

of Solomon's Temple. What we do know for certain is that Justinian 'built' not a floor but a heaven of glass with a golden background to crown his temple, and thus continued the dream of crystal architecture. Hagia Sophia marked the first time that this dream was materialised on a large scale, (Fig. 2) with glass-clad walls that transmit the symbolism of light that can 'illuminate' humanity.

In the first centuries of Christianity, when the greatest works of early Byzantine architecture were produced, anagogical light filled the thoughts of the church fathers under the influence of neoplatonist authors like Plotinus. Although the manner in which the 'aesthetics of light' became elaborated in Christianity on the basis of classical philosophy (16) lies beyond the scope of this text, we consider it worthwhile, within the context at hand, to quote part of a core Patristic text, The Confessions of Saint Augustine, in which Augustine of Hippo refers to the transcendental role of light in reaching divine knowledge: "Are there not many who $[\ldots]$ are illuminated by that light which gives those who receive it power to become Thy sons?” (17)

Continuing the narrative, the 'Digenes Akrites', an epic poem from the late 9th Century or early 10th Century, which met with great success in Byzantium since the middle empire, once again mentions "watery" land. "The floor he paved with onyx stones, so firmly polished that those who saw it might think water was there, congealed in ice" (18) For centuries, Hagia Sophia's marble floor was imagined to be an 'icy sea'. This perception of stone as a frozen liquid substance led to similar descriptions of other medieval Eastern and Western churches, regarded as evocations of the primeval chaos and theological images of the sea on which the faithful "walked on water". (19) 
lo veían se engañaban creyendo que era agua congelada en hielo". (18) Por ello, durante siglos, el suelo de mármol de Santa Sofía se imaginó como un 'mar helado'. Esta percepción de la piedra como una sustancia líquida congelada condujo a descripciones similares de otras iglesias medievales, orientales y occidentales, evocando simultáneamente el caos primigenio y las imágenes teológicas del mar sobre el que los devotos "caminan sobre el agua". (19)

En la literatura árabe de la Alta Edad Media, la asociación de la arquitectura de vidrio con Salomón adquiere un tono sobrenatural. Este rey aparece siempre ligado a la construcción de edificios fantásticos, con la ayuda de genios sometidos mágicamente. En las Historias de los Profetas de ath-Thāāibī, se lee: "Salomón ve cómo se levanta del fondo del mar un pabellón, [...] como una cúpula, hecha de cristal y azotada por las olas [...] La ciudad del aire es erigida por los genios siguiendo el mandato de Salomón, que les mandó construir una ciudad o un palacio de cristal de cien mil brazas de extensión y mil pisos de altura [...] con una cúpula airosa y más ligera que agua [...] transparente, de modo que la luz del sol y de la luna puedan penetrar a través de sus paredes". (20) Estos relatos dotan a Salomón de poderes que hacen comprender la vinculación posterior de su nombre, con la alquimia y las logias cabalísticas.

La combinación de agua y luz para elaborar una atmósfera arquitectónica fantástica, fue recurrente en las cortes islámicas de este periodo y es evocada claramente en el Palacio de la Alhambra, apareciendo también en narraciones con el vidrio como elemento añadido, como la que refiere el pabellón construido para el rey de Toledo Yahyā ibn Ismāil al-Ma’mūn en el siglo xi: "Construyó en medio de su palacio un lago, en el centro del cual edificó un pabellón con vidrieras y con incrustaciones de oro. El agua se conducía a la parte alta del pabellón mediante un ingenioso dispositivo inventado por sus ingenieros, (21) de manera que el agua descendía desde la cumbrera en un sinfín regueros que se unían entre sí. De esta manera, el pabellón de vidrio se encontraba bajo una lámina de agua que se deslizaba a través del cristal y

In the Late Middle Ages, the association between glass architecture and King Solomon took on a supernatural dimension in Arabic literature. Solomon was constantly associated with the construction of fantastic buildings, aided by magically subjected genies. In Tales of the Prophets, ath-Tha'ālibì writes: "Solomon saw a pavilion rise from the bottom of the sea, [...] like a dome, made of glass and whipped by the waves [...] The city in the air was built by genies under Solomon's orders, who commanded them to build a city or a palace of crystal one hundred thousand fathoms in length and a thousand storeys high [...] with an airy dome, lighter than water [...] transparent to let the light of the sun and the moon penetrate its wall". (20) These stories attribute Solomon with extraordinary powers that explain the subsequent association of his name with alchemy and Kabbalistic orders.

The combination of water and light to create fantastic architectural atmospheres was a recurrent theme in the Islamic courts of the time. This is clearly evoked in the Alhambra Palace, also mentioned in contemporary descriptions, where glass is an added element. A description of the pavilion built in the 11th Century for the King of Toledo, Yahyā ibn Ismā'il al-Ma'mūn, says that: "In the middle of his palace he built a lake, and in the centre, he built a pavilion with stained-glass windows and gold inlays. The water was channelled to the top of the pavilion by means of an ingenious device invented by his engineers, (21) in such a way that the waters descended from the ridge in endless streams and merged together again. The glass pavilion was thus beneath a sheet of water that slid through the glass and flowed incessantly, while al-Ma'mūn sat inside without getting wet. Torches could even be lit in there, producing an amazing, marvellous spectacle" (22) 
que fluía incesantemente, mientras al-Ma'mūn se sentaba en el interior sin mojarse; y hasta las antorchas podían encenderse en él, produciendo, por lo tanto, un espectáculo asombroso y maravilloso". (22)

Las tradiciones judeo-cristiana y musulmana se unificarán en otras de carácter ecléctico, propiciadas por la convivencia de ambas culturas durante la Edad Media. Todas estas tradiciones van a formar el trasfondo literario que acompañará el nacimiento y desarrollo del estilo gótico, que con sus vidrieras será otro paso más, tras Bizancio, en la materialización del sueño de la arquitectura de cristal. La luz anagógica vuelve a ser el leitmotiv de la arquitectura religiosa de la mano del Abad Suger, que 'inventa' el gótico en la Basílica de Saint-Denis, interpretando y 'aplicando' los escritos de un seguidor de Plotino, el Seudo Dionisio Areopagita: "Nosotros, los hombres, no podríamos en modo alguno elevarnos por vía puramente espiritual a imitar y contemplar las jerarquías celestes sin ayuda de medios materiales que nos guíen como requiere nuestra naturaleza. Cualquier persona, reflexionando, se da cuenta de que la hermosura aparente es signo de misterios sublimes [...] Las luces materiales son imagen de la copiosa efusión de luz inmaterial". (23) Suger elige la luz como canal de la belleza divina, a través de materiales como los metales preciosos, las gemas o las vidrieras de Saint-Denis para hacerla llegar, por medio del sentido de la vista, hasta el hombre. Si en la arquitectura Bizantina, la 'luz sobre' o la 'luz desde' los mosaicos de vidrio de fondo de oro construyó un cielo titilante, en la catedral gótica, la 'luz a través' de las vidrieras construyó una envolvente 'radiante'; en ambos casos, con el fin de alcanzar anagógicamente lo inteligible. (24)

Siguiendo con nuestro trasfondo literario vemos cómo en La carta del Preste Juan, un texto anónimo que comenzó a circular por Europa hacia el 1165, este personaje mítico mitad rey y mitad sacerdote muy popular entre los siglos XII y XVI, relata que en su palacio el techo es "[...] de zafiros brillantísimos, mientras que los esplendorosísimos topacios han sido dispuestos entre aquellos para que los zafiros, al modo de un cielo sin nu-

In the Middle Ages, Judeo-Christian and Muslim traditions merged with those of a more eclectic nature, propitiated by the cohabitation of the two cultures. All these traditions formed a literary backdrop to the emergence and development of Gothic architecture. Gothic stained glass windows were a major step forward in the materialization of the dream of glass architecture following the decline of Byzantium. Anagogical light once again became the leitmotiv for religious architecture in the hands of Abbot Suger, the 'inventor' of the Gothic in the Saint-Denis Basilica, where he interpreted and 'applied' the texts of Pseudo Dionysus Areopagite, a follower of Plotinus: "We men can in no way elevate ourselves by purely spiritual means in order to imitate and contemplate the celestial hierarchies without the aid of material resources that guide us as required by our nature. Any thinking person will realise that apparent beauty is a sign of sublime mysteries. [...] Material lights are an image of the copious effusion of immaterial light". (23) Suger chose light as a channel for divine beauty, employed in the form of precious metals, gems and the stained-glass windows in Saint-Denis to allow it to reach humans through our sense of sight. In Byzantine architecture, the 'light on' or 'light from' the glass mosaics with their gold background constructed an extremely attractive heaven, while in the Gothic cathedral, the 'light through' the stained glass windows created an enveloping 'radiance', in both cases aimed at attaining the intelligible in an anagogy. (24)

Continuing this literary overview, the Letter of Prester John, an anonymous text that began to circulate in Europe around 1165 , contains a description of the palace of this mythical priest-king figure, popularised between the 11th and 16th Centuries: "[...] Its heaven, that is its roof, is of the clearest sapphire, and the brightest topazes, in the 
bes y los topacios, al modo de las estrellas iluminen el palacio. En verdad que el pavimento está formado por grandes losas de cristal". (25) Y ante las puertas de ese palacio, hay un espejo de grandísimo tamaño, colocado sobre un inverosímil tinglado de columnas y plataformas superpuestas, al que se asciende por peldaños de pórfido, serpentina, alabastro, cristal, sardónice, amatista, jaspe y ámbar, en el que puede verse y conocerse por los vigilantes todo cuanto a favor y en contra del rey se hace. (26)

Por esos mismos años Chrétien de Troyes, como máximo representante del nuevo género literario Le Roman (que aparece en Francia, cuna del gótico, a mediados del siglo XII), inaugura la popularidad de los relatos en torno al mundo artúrico y el tema del Grial, con su obra Perceval ou Li Contes del Graal. En el libro, Perceval consigue llegar al castillo en donde el Grial está al cuidado del Rey Pescador. Cuando el Grial le es mostrado, éste manifiesta todos los atributos de la divinidad: brilla como el sol y está lleno de piedras preciosas. (27) También del siglo XII es el texto anónimo conocido como Folie d'Oxford, donde aparece un Palais de verre suspendido entre el cielo y la tierra. El poema Parzival, escrito por Wolfram von Eschenbach a principios del siglo XIII, retoma el relato de Chrétien y en él, describe el Santo Grial como una piedra preciosa que Lucifer había desprendido de la corona de Dios cuando le estaba desterrando del paraíso, y que Adán guardaba en una cueva. (28) Esta alusión, a que la piedra sagrada que contiene la luz divina está guardada en una cueva, conjuga las imágenes de la luz y la sombra que son habituales en los escritos místicos y que serán recurrentes en tradiciones alquímicas posteriores. (29)

Hacia el 1250, un escriba de La carta del Preste Juan añadió al texto la descripción de una Capella vítrea; esta arquitectura 'escrita' de cristal es coetánea de la Sainte-Chapelle de París. (30) (Fig. 3) En el Jüngerer Titu$r e l$, narrada en el último tercio del siglo xiı por Albrecht von Scharfenberg y que reproduce gran parte del texto de la Carta del Preste Juan, se cuenta que el Grial está guardado en las montañas de Monserrat, que en
Fig. 3: Montreuil, Pierre: Sainte-Chapelle, 1241-1248

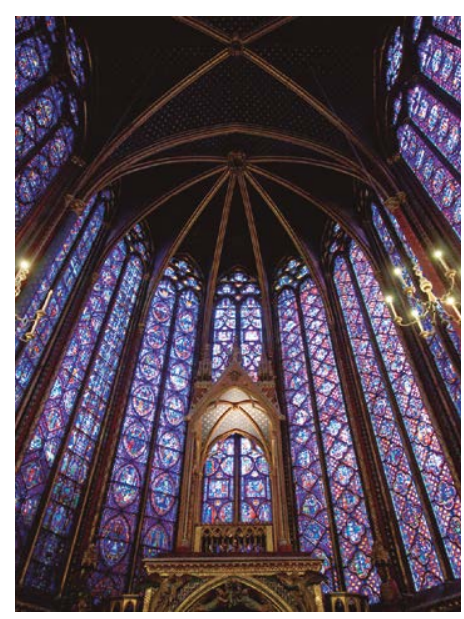

manner of stars, illuminate the palace. Indeed the floor is of large crystal flagstones". (25) Moreover, in front of the gates of this palace is a gigantic mirror that rests on an implausible set of columns and superimposed platforms, reached by a staircase of porphyry, serpentine, alabaster, crystal, sardonyx, amethyst, jasper and amber in which everything done for and against the king can be discovered and known by the watchmen. (26)

In the mid-12th Century, Chrétien de Troyes, the maximum exponent of the new Le Roman literary genre in France, the cradle of the Gothic, popularised stories about the realm of King Arthur and the Holy Grail in Perceval ou Li Contes del Graal. In this book, Perceval comes to the castle where the Grail is guarded by the Fisher King. When he is shown the Grail, it manifests all its divine attributes, full of precious stones, shining like the sun. (27) Another anonymous 12th Century text, Folie d'Oxford, describes a Palais de verre suspended between heaven and earth. Wolfram von Eschenbach's early 13th Century poem Parzival takes up Chrétien's story in its description of the Holy Grail, as a precious stone held by Adam in a cave that Lucifer had removed from God's crown when he was banished from Paradise. (28) This reference to the idea of a sacred stone containing divine light. That is stored in a cave conjugates the images of light and shadow, recurrent in subsequent essays on alchemy. (29)

Around 1250, an addendum to the Letter of Prester John included a description of a vitreous chapel. This 'written' glass architecture was contemporary to the Sainte-Chapelle in Paris. (30) (Fig. 3) In the final third of the 13th Century by Albrecht von Scharfenberg penned Jüngerer Titurel, which reproduces much of the Letter of Prester 
el poema se describen como un acantilado de ónix, en el que después de ser desbrozado y pulido por Titurel, aparecen milagrosamente las trazas de un monasterio. Su exterior era como una corona gigante con el techo de oro y esmalte, que resplandecía al sol. Rubíes resplandecientes culminan las torres y la luz de un carbunclo en la cúspide de la torre central guía el camino de los templarios. En el interior la luz es mística y las ventanas no tienen vidrio sino piedras preciosas; el suelo era un mar de cristal y como si se mirara a través de una fina capa de hielo, se podían ver olas y peces bajo él; un detalle, este último, que desvela su relación con las leyendas del palacio de Salomón. (31)

Igualmente, la literatura secular de la Baja Edad Media creó nuevos atributos para el simbolismo del cristal, no sólo relativas a la espiritualidad, sino movilizando ideas que también se relacionan a la condición humana más terrena, y que se traslucirán en los periodos posteriores, romántico y expresionista. Por nombrar alguna de estas obras habría que citar Tristan de Gottfried von Strassburg, completado hacia 1210, donde el autor narra los amores de Tristán e Isolda y describe la Gruta de los Amantes, lugar maravilloso en cuyo centro hay un lecho tallado en cristal de roca que simboliza el amor transparente y puro; (32) o The Temple of Glass de John Lydgate, ya de principios del siglo $\mathrm{xv}$, donde el protagonista cae en un profundo sueño y es transportado a un templo de cristal que se halla en una helada montaña. (33)

Una obra tardía, que resume prácticamente todas estas tradiciones medievales literarias del simbolismo del cristal, es la obra de Francesco Colonna publicada en Venecia en 1499 y titulada Hypnerotomachia Poliphili, (34) en la que sincréticamente se unifican las metáforas creadas por los místicos religiosos: la alquimia y la poesía de amor cortesano. Además de piedras preciosas y exóticos materiales en una abundancia desbordante, en la narración aparecen " [...] jardineras cuyas plantas, en lugar de ser naturales, estaban hechas todas de purísimo vidrio, arquitrabes, frisos y cornisas [...] proyectándose debidamente sobre el capi-

John, it claims that the Holy Grail is stored in the Montserrat range, near Barcelona, described in the poem as a cliff of onyx in which, after being cleaned and polished by Titurel, the traces of a monastery appear miraculously. Its facade is like a giant crown with a gold and enamel roof that shines in the sun. Sparkling rubies cap the towers and the light of a carbuncle at the pinnacle of the central tower guides the Templars' path. Inside, the light is mystical and the windows are not glass but precious stones. The floor is a sea of glass, as if one were looking through a thin layer of ice, with waves and fish beneath, a detail that belies a connection to the legends of King Solomon's palace. (31)

Secular literature in the Late Middle Ages also conjured up new attributes for the symbolism of glass, related, not only to spirituality but also to the earthly human condition. This aspect was subsequently elaborated on in the Romantic and Expressionist periods. In one such work, Gottfried von Strassburg's Tristan, completed around 1210, the author narrates the love of Tristan and Isolde and describes the Lovers' Grotto, a marvellous place with a bed in the centre carved out of rock crystal, a symbol of pure, transparent love. (32) In John Lydgate's early 15th Century Temple of Glass, the hero falls into a deep slumber and is carried to a crystal temple on a frozen mountain. (33)

One of the late works from this period that summarises nearly all these medieval literary traditions of crystalrelated symbolism, Hypnerotomachia Poliphili (34) published by Francesco Colonna in Venice in 1499, syncretically blends the metaphors shaped by religious mystics, alchemy and the poetic genre of courtly love. Precious 
tel de vidrio de las columnas, un jardín [...] pavimentado con círculos de vidrio". (35) El simbolismo en torno al cristal, el vidrio, las piedras preciosas, la luz y el oro de la Baja Edad Media se mantendrá vivo en la alquimia a lo largo de los siglos posteriores, y aunque el predominio de las ciencias positivas durante lo que se denomina Edad Moderna, entre los siglos xv y xviII, mantendrá aparentemente inactivo el sueño de la arquitectura de cristal, podemos encontrar alguna manifestación del mismo en la pintura flamenca de finales del siglo $\mathrm{xv}$ y principios del siglo xvi. (36) (Figs. 4 y 5 )

El descubrimiento de América, en el siglo xv, amplia el conocimiento de las tierras conocidas, y lo descubierto en ellas es tan sorprendente y fascinante como las invenciones literarias de los siglos precedentes. Copérnico y Galileo abren nuevas posibilidades de asombro, mirando al cielo, y la publicación en 1605 de la primera parte de El Quijote asesta el golpe definitivo a las novelas del ciclo artúrico de las que hemos hablado. No obstante, el sueño de la arquitectura de cristal, sigue latente. Surgido hace más de tres mil años en el Mediterráneo oriental, este sueño se extendió a lo largo de los siglos avanzando hacia poniente. Vuelve

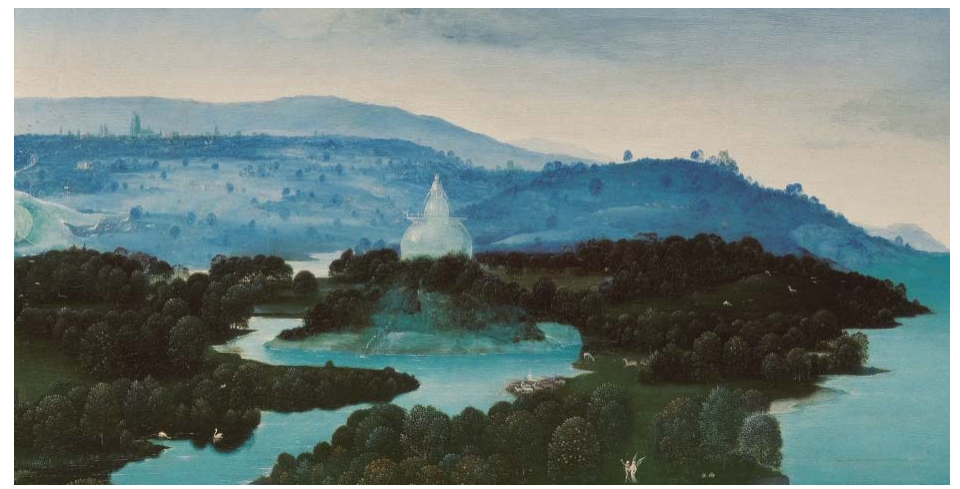

Fig. 4: Bosch, Jheronimus: El jardín de las delicias, 1490-1500 (tríptico cerrado: La Creación del Mundo)

Fig. 5. Patinir, Joachim: El paso de la laguna Estigia, 1520-1524 (detalle del cuadro)

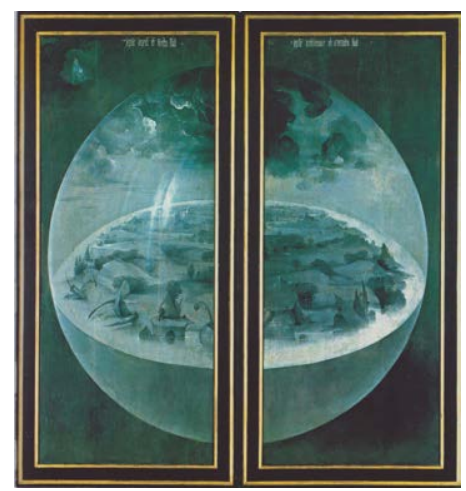

stones and exotic materials in boundless abundance appear in the story, along with, "[...] pots with plants which are not natural but made of pure glass, architraves, friezes and cornices [...] projected onto the glass capitals of the columns, a garden [...] paved with glass circle". (35) The symbolism of crystal, glass, precious stones, light and gold from the early Middle Ages was kept alive by alchemy in the following centuries, although the prevalence of positive science in the so-called Modern Age, between the 15th and 18th Centuries, seemed to defuse the dream of glass architecture, we can find some manifestation of it in Flemish painting at the end of the 15th and early 16th Centuries. (36) (Figs. 4 \& 5)

The discovery of America in the 15th Century expanded European knowledge of other lands, with new images that proved to be no less astonishing and fascinating than the literary inventions of the preceding centuries. Copernicus and Galileo opened up more astonishing frontiers by gazing at the sky, and the publication of the first part of Don Quixote in 1605 dealt a final blow to the Arthurian novels. Nevertheless, the dream of crystal architecture stayed alive, albeit in a latent state. A dream that emerged more than 3000 years ago in the eastern Mediterranean advanced in the course of the centuries and spread westwards. It reappeared vigorously in the 17th Century, thanks to the use of mirrors in architecture. The Palace of Versailles became a paradigm, with spaces once again dominated by the reflection of light on glass, symbolizing the magnificence of a Sun King who merged religious and secular power. 


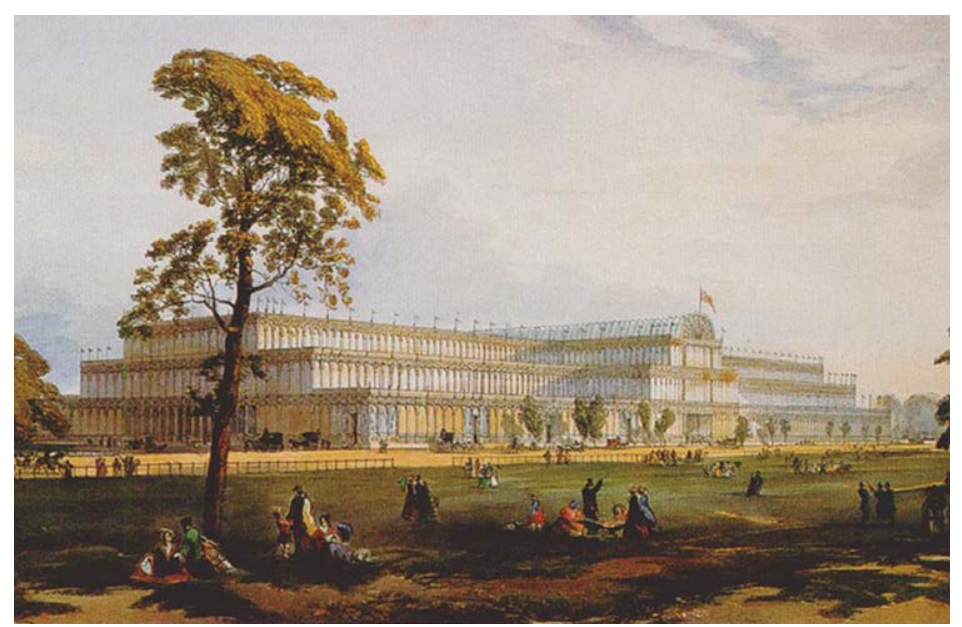

a aparecer pujante en el siglo XVII, con la incorporación de espejos en la arquitectura y con el Palacio de Versalles como paradigma, donde nuevamente un espacio dominado por el reflejo de la luz en el vidrio simbolizará la magnificencia del Rey Sol, quien aglutina los poderes religiosos y laicos.

También a mediados del siglo xix, con el surgimiento de las primeras auténticas catedrales de cristal: los grandes invernaderos. La imagen del Crystal Palace de Paxton, (Fig. 6) desde su construcción en 1851, será el edificio que influya en toda la literatura y arquitectura utópica posterior. Con la vista puesta en invernaderos como el de Paxton, el mesianismo asociado al vidrio vuelve a dar pruebas de su indeclinable fe; ahora, con el advenimiento de la revolución industrial, ese material ayudará en la creación de los nuevos espacios arquitectónicos que la nueva 'fe' en el progreso necesita para el mercado y el estado, creando

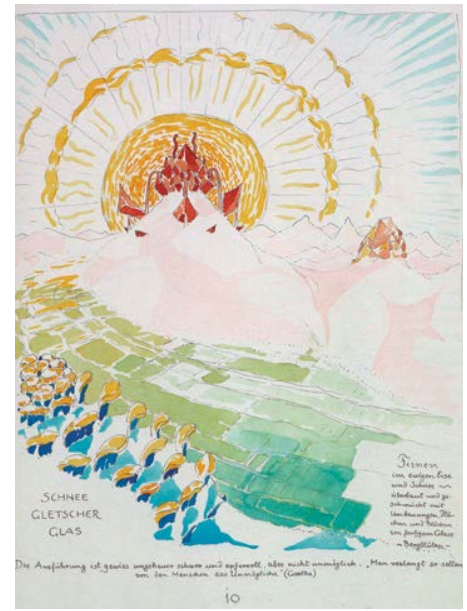

Fig. 6. Paxton, Joseph: Crystal Palace, 1851. Fig. 7. Ilustración. Taut, Bruno: 'Segunda parte. Arquitectura en las Montañas', Arquitectura alpina, 1917-1919.

The first veritable glass cathedrals were built in the middle of the 19th Century, in the form of huge greenhouses. From the moment of its construction in 1851, the image of Paxton's Crystal Palace (Fig. 6) had a major influence on all utopian literature and architecture. Crystal-related messianism now focused its sights on greenhouses like Paxton's, further evidence of its unquenchable faith. This time, with the advent of the Industrial Revolution, glass helped to shape novel architectural spaces that the new liberal 'faith' in progress required for the market and the state, in order to create new utopias. The work of Paul Scheerbart and Bruno Taut (Fig. 7) contains obvious references to the tradition discussed here. (37) Looking further afield, Vladimir E. Tatlin, (Fig. 8) Ivan Leonidov, (Fig. 9) Mies van der Rohe, and Buckminster Fuller (Fig. 10) have also provided continuity to the dream in a secular twist to the 'anagogy' propitiated by glass. (38)

In the course of the extraordinarily long life of the dream of crystal architecture, glass has been used in architectures to serve the power of the church, the monarchy, the state and the market. As we have seen, in Western culture, light has always been associated with revelation and 'anagogy', both religious and secular, and glass has been a means to achieve it in these architectures. All of this, as mentioned initially, has been thanks to the seductive attraction to the human mind of its powerful latent mystery, only revealed when it enters into contact with light. 
nuevas utopías. La obra de Paul Scheerbart y de Bruno Taut, (Fig. 7) evidentemente, nos remiten a la tradición que venimos narrando, (37) pero también la de Vladimir E. Tatlin, (Fig. 8) Ivan Leonidov, (Fig. 9) Mies van der Rohe o Buckminster Fuller, (Fig. 10) que consideramos han dado continuidad a ese sueño, donde la 'anagogía' propiciada por el cristal se ha hecho laica. (38)

Durante el largo tiempo que ha durado el sueño de la arquitectura de cristal, el vidrio ha hecho surgir arquitecturas al servicio del poder de la iglesia, la monarquía, el estado o el mercado. Si como hemos visto, la luz en la cultura occidental se ha asociado siempre con la revelación y la 'anagogía' religiosa o laica, el vidrío ha sido la vía de acceso a la misma en esas arquitecturas. Y todo ello, como dijimos al comienzo, como resultado de la seducción producida en el hombre por el potencial de misterio latente en el mismo, puesto al descubierto al entrar en relación con la luz.
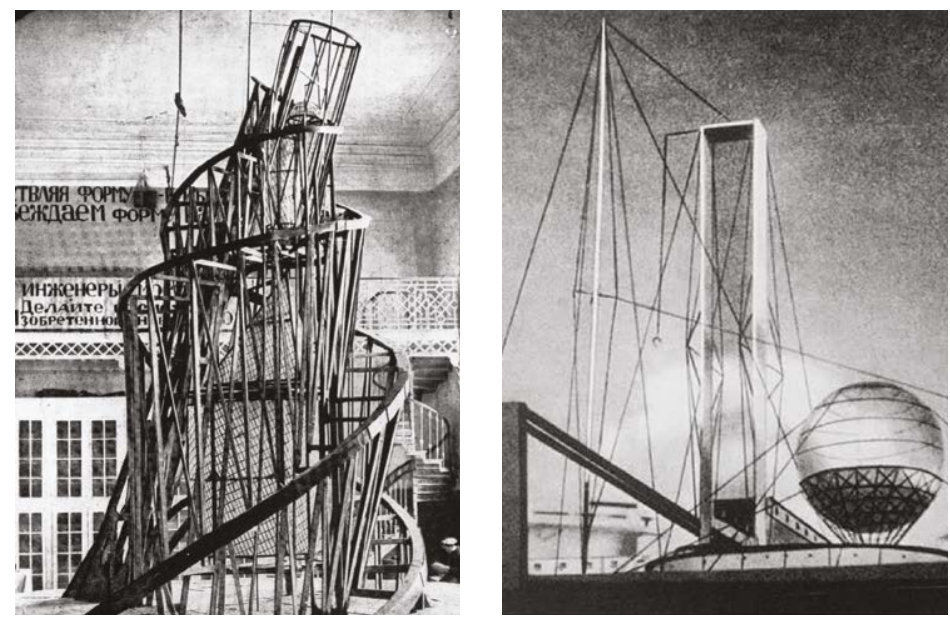

Fig. 8. Tatlin, Vladimir E.: Proyecto para el monumento de la Tercera Internacional, 1920Ç Fig. 9. Leonidov, Ivan: Proyecto para el Instituto Lenin, 1927.

Fig. 10. Fuller, Buckminster: Proyecto de cúpula geodésica sobre Manhattan, ca. 1960.

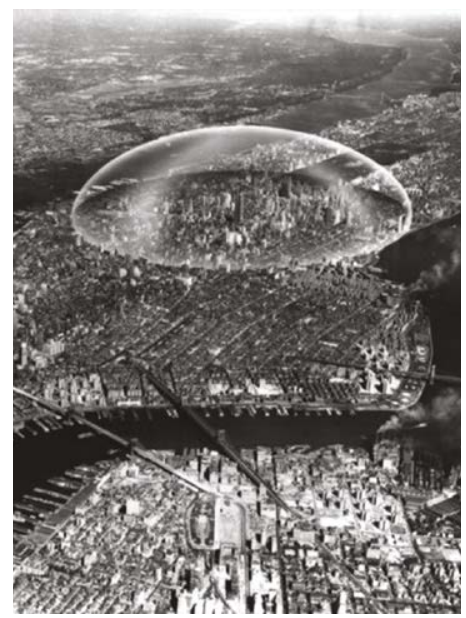

\section{NOTAS}

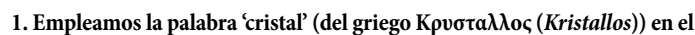
título, en lugar de 'vidrio' por ser la que aparece en los textos que citamos en el artículo como origen de la mítica en torno a la arquitectura de vidrio. La palabra vidrio se emplea en el texto para referirnos al material de construcción en sí, en sus aspectos más ligados a la técnica.

2. La luz, y por lo tanto el vidrio por su relación con ella, estuvo desde el principio investida de una capacidad de provocar "elevación y enajenamiento del alma en la contemplación de las cosas divinas". DRAE. Para más información sobre el sentido anagógico de la luz en la arquitectura gótica y bizantina ver: NIETO ALCAIDE, V. La luz, símbolo y sistema visual.

3. A este respecto consultar: KURINSKY, S. The Glass Makers; MOOREY, P. R. S. Ancient Mesopotamian Materials; TAIT, H. (ed.). Five Thousand Years of Glass; WHITEHOUSE, D. Glass, A Short History.

4. PIRENNE, J. Historia de la civilización del Antiguo Egipto. p. 31.

5. Para más información sobre las evidencias arqueológicas de la producción de vidrio en Amarna y sobre la propia ciudad, ver: LABOURY, D. Akhenatón; NICHOLSON, P.T. Brilliant Things for Akhenaten.

6. Apocalipsis 4: 5-6.

7. GINZBERG, L. The Legends of the Jews. p. 145. El Targum Shenī es una paráfrasis en arameo del Libro de Ester, adornado con una gran cantidad de
NOTES

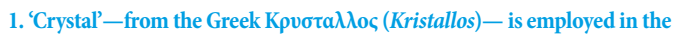
title instead of 'glass' due to the former term's attribution in the cited texts as the origin of the mythical image of glass architecture. The word 'glass' is used to refer to the building material and its technical aspects.

2. From the outset, light - and hence glass, due to their interrelationshiphas been invested with the ability to produce an "elevation and alienation of the soul in the contemplation of divine things". (DRAE). For more information on the anagogical sense of light in Gothic and Byzantine architecture see: NIETO ALCAIDE, V. La luz, símbolo y sistema visual.

3. On this aspect, see: KURINSKY, S. The Glass Makers; MOOREY, P.R.S.

Ancient Mesopotamian Materials; TAIT, H. (ed.). Five Thousand Years of Glass; WHITEHOUSE, D. Glass, A Short History.

4. PIRENNE, J. Historia de la civilización del Antiguo Egipto. p. 31.

5. For more archaeological evidence of glass production in Amarna and the city itself, see: LABOURY, D. Akhenatón; NICHOLSON, P.T. Brilliant Things for Akhenaten.

6. Revelation 4:5-6.

7. GINZBERG, L. The Legends of the Jews. p. 145. The Targum Sheni is an Aramaic paraphrase of the Book of Esther, adorned with a considerable amount of apocryphal material including this episode, which does not appear in its predecessor, dating from between the 5 th and the 2 nd centuries $\mathrm{BC}$. 
materiales apócrifos, incluido el episodio que hemos narrado, que no aparece en su predecesor, datado entre el siglo $\mathrm{v}$ y el II a.C.

8. GINZBERG, L. The Legends of the Jews. p. 289.

9. Corán. p. 332.

10. Sobre las especulaciones que históricamente han relacionado o identificado a Moisés con Akenatón, ver: ASSMANN J. Moisés el egipcio; KRAUSS R. Moïse le Pharaon; FREUD, S. Moisés y la religión monoteísta.

11. Éxodo 14, 15-23.

12. BEN-SASSON, H. (ed.). Historia del pueblo judío. p. 61.

13. Mateo 14: 22-33.

14. Reyes 6: 15-20.

15. KRAUTHEIMER, R. Arquitectura Paleocristiana y Bizantina. p. 241.

16. A este respecto consultar: BRUYNE, E. de. La estética de la Edad Media. 17. HIPONA, A. Confesiones. p. 158.

18. YARZA, J., GUARDIA, M., y VICENS, T. (eds.). Arte Medieval. p. 285. 19.BARRY, F. 'Walking on Water'. Cosmic Floors in Antiquity and the Middle Ages. pp. 627-656. Sobre esta idea arquetípica de los pavimentos como mares (y de los techos como cielos) ver también: LETHABY, W.R. Architecture, Mysticism and Myth.

20. BARGEBUHR, F. El palacio de La Alhambra en el siglo XI. p. 60.

21. Según Bargebuhr, se evidencia en todas estas narraciones, el conocimiento que el mundo islámico tenía de los 'ingenios' bizantinos, entre los que se encontraban los hidráulicos. Ibidem. pp. 99-103.

22. BARGEBUHR, F. The Alhambra: A cycle of Studies. p. 144.

23. AREOPAGITA, S.D. Obras completas. p.121.

24. Las fuentes literarias bizantinas recogen, desde una interpretación anagógica, que la luz 'emanaba' directamente de los mosaicos; de ahí que nos refiramos a la luz por ellos reflejada como 'luz-sobre' o 'luz-desde'. Por otro lado, en relación a la luz gótica que atraviesa las vidrieras, 'luz-a través', utilizamos el adjetivo 'radiante' para caracterizar su envolvente, haciendo referencia al término rayonnement que emplea Viollet-le-Duc en la entrada 'Vitrail' de su Dictionnaire raisonné, donde explica el efecto de irradiación, que se produce en las catedrales góticas, al incidir la luz en los vidrios de diversos colores, haciendo que estos interactúen entre sí. VIOLLET-LE-DUC, E. 'Vitrail'. p. 384.

25. Anónimo. La carta del Preste Juan. p. 103

26. Ibidem. p. 101.

27. CIRLOT, V. Figuras del destino. pp. 145-71.

28. La mayoría de las leyendas en torno al Santo Grial parten de fuentes orientales. La versión de Eschenbach específicamente se inspira en un poeta provenzal que a su vez había escrito su versión a partir de un manuscrito árabe. FRANKL, P. The Gothic: Literary Sources. pp. 177-9.

29. BLETTER, R. Bruno Taut and Paul Scheerbart's Vision. p. 280.

30. FRANKL, P. Opus. cit. pp. 175-76.

31. Ibidem. pp. 180-82.

32. Ibidem. p. 173.

33. Ibidem. p. 194.

34. COLONNA, F. Sueño de Polífilo.

35. Ibidem. pp. 243-44.

36. El simbolismo religioso del cristal lo vemos plasmado en dos cuadros flamencos: El jardín de las delicias, de El Bosco y El paso de la Laguna Estigia, de Patinir.

37. Rosemarie Haag Bletter recoge en su tesis que algunas de las leyendas que hemos incluido en el artículo son fuentes de inspiración de la facción cristalina del movimiento expresionista alemán. Nuestra aportación consiste en ampliar tanto las fuentes citadas por esta autora, como las influencias de las mismas en otros movimientos coetáneos y posteriores al Expresionismo. 38. Para una explicación más extensa de la pervivencia del sueño de la arquitectura de cristal en estos autores, ver: RUBIO HERNÁNDEZ, R. El vidrio $y$ sus máscaras. El sueño de la arquitectura de cristal.
8. GINZBERG, L. The Legends of the Jews. p. 289.

9. Quran [online]. [Consulted 18/12/2018]. Available in: [http://www.wrighthouse.com/religions/islam/Quran/27-ant.php].

10. For speculations that have historically related or identified Moses with Akhenaten, see: ASSMANN J. Moses the Egyptian; KRAUSS R. Moïse le Pharaon. FREUD, S. Der Mann Moses und die monotheistische Religion.

11. Exodus 14, 15-23.

12. BEN-SASSON, H. (ed.). A History of the Jewish People. p. 61.

13. Matthew 14: 22-33.

14. Kings 6: 15-20.

15. KRAUTHEIMER, R. Early Christian and Byzantine Architecture. p. 241.

16. In this regard, see: BRUYNE, E. de. The Esthetics of the Middle Ages.

17. HIPPO, A. Confessions [online]. [Consulted 18/12/2018]. Available in:

[https://en.wikisource.org/wiki/The_Confessions_of_Saint_Augustine_

(Outler)/Book_VIII].

18. YARZA, J.; GUARDIA, M.; VICENS, T. (eds.). Arte Medieval. p. 285.

19. BARRY, F. 'Walking on Water'. Cosmic Floors in Antiquity and the Middle

Ages. pp. 627-656. On this archetypal idea of floors as seas - and roofs as

skies- see also: LETHABY, W.R. Architecture, Mysticism and Myth.

20. BARGEBUHR, F. The Alhambra Palace of the Eleventh Century. p. 60.

21. Bargebuhr claims that the Islamic world's knowledge of Byzantine "ingenuities" including hydraulics, is evidenced in these stories. Ibid. pp. 99-103. 22. BARGEBUHR, F. The Alhambra: A cycle of Studies on the Eleventh Century in Moorish Spain. p. 144.

23. AREOPAGITA, S.D. Obras completas. p. 121.

24. Byzantine literary sources, in an anagogical interpretation, speak of the light that 'emanates' directly from the tiles, hence our reference to the light reflected by, 'on' or 'from' them. When describing the Gothic light that traverses stained glass windows - 'light through' - we use the adjective 'radiant' to describe its sense of envelopment, also in reference to the term rayonnement employed by Viollet-le-Duc in the entry 'Vitrail' of his Dictionnaire raisonné, where he explains the effect of irradiation in Gothic cathedrals, where light strikes glass of different colours, triggering their interaction with each other. VIOLLET-LE-DUC, E. 'Vitrail'. p. 384.

25. Anonymous. Prester John: The Legend and Its Sources. p. 92.

26. Ibidem. p. 101.

27. CIRLOT, V. Figuras del destino. pp. 145-171.

28. Most legends concerning the Holy Grail are from Eastern sources.

Eschenbach's version was inspired by a Provençal poet, who in turn had written his version on the basis of an Arabic manuscript. FRANKL. p. The Gothic: Literary Sources. pp. 177-9.

29. BLETTER, R. Bruno Taut and Paul Scheerbart's Vision. p. 280.

30. FRANKL, P. Opus. cit. pp. 175-76.

31. Ibidem. pp. 180-182.

32. Ibidem.p. 173.

33. Ibidem. p. 194.

34. COLONNA, F. Hypnerotomachi [online]. [Consulted 18/12/2018]. Avail-

able in: [http://www.gutenberg.org/files/18459/18459-h/18459-h.htm].

35. Ibidem. pp. 243-244.

36. The religious symbolism of glass is reflected in two Flemish paintings:

The Garden of Earthly Delights, by El Bosco and Charon Crossing the Styx, by Patinir.

37. Rosemarie Haag Bletter explains that some of the legends mentioned in the present text were a source of inspiration for the 'Crystal Chain' of the German Expressionists. Our aim with this paper is to expand on the sources mentioned by Bletter and their influence on other contemporary and subsequent movements.

38. For a more extensive explanation of the continuity of the dream of crystal architecture in these authors, see: RUBIO HERNÁNDEZ, R. El vidrio y sus máscaras. El sueño de la arquitectura de cristal. 


\section{REFERENCIAS}

Anónimo, La carta del Preste Juan. Madrid: Ediciones Siruela, 2004. ASSMANN J. Moisés el egipcio. Madrid: Oberón Grupo Anaya, 2003. BARGEBUHR, F. El palacio de La Alhambra en el siglo XI. México: Graduate College, State University of Iowa, 1966.

BARGEBUHR, F. The Alhambra: A Cycle of Studies on the 11th Century in Moorish Spain, Walter de Berlín: Gruyter and Co., 1968.

BARRY, F. 'Walking on Water. Cosmic Floors in Antiquity and the Middle Ages.' The Art Bulletin, 2007, 89(4). pp. 627-656.

BELTING, H. El Bosco. El jardín de las delicias. Madrid: Abada Editores,

2016.

BEN-SASSON, H. (ed.) Historia del pueblo judío. Desde los orígenes hasta la Edad Media. Madrid: Alianza Editorial, 1988.

Biblia de Jerusalén. Bilbao: Desclee De Brouwer, 1999.

BLETTER, R. H. Bruno Taut and Paul Scheerbart's Vision: Utopian Aspects of German Expressionist Architecture. (Tesis doctoral inédita). Nueva York: Columbia University, 1973.

BRUYNE, E. de. La estética de la Edad Media. Madrid: Antonio Machado Libros, 2010.

CIRLOT, V. Figuras del destino. Mitos y símbolos de la Europa medieval. Madrid: Ediciones Siruela, 2005.

COLONNA, F. Sueño de Polífilo. Barcelona: Acantilado, 2008.

Corán. Barcelona: Editorial Planeta, 2014.

FRANKL, P. The Gothic: Literary Sources and Interpretations through Eight Centuries. Princeton: University Press Princeton, 1960.

FREUD, S. Moisés y la religión monoteísta. Buenos Aires: Editorial Losada, 1960.

GINZBERG, L. The Legends of the Jews. vol. IV: Bible Times and Characters from the Joshua to Esther. Filadelfia: The Jewish Publication Society of America, 1913.

GINZBERG, L. The Legends of the Jews. vol. vI: Notes to Volumes II and IV. From Moses in the Wilderness to Esther. Filadelfia: The Jewish Publication Society of America, 1946.

HIPONA, A. Confesiones. Madrid: Espasa Calpe, 1983.

KRAUSS, R. Moïse le Pharaon. Mónaco: Les Editions du Rocher, 2000. KRAUTHEIMER, R. Arquitectura Paleocristiana y Bizantina. Madrid: Ediciones Cátedra, 2011.

KURINSKY, S. The Glass Makers: an Odyssey of the Jews. The First Three

Thousand Years. Nueva York: Hippocrene Books, 1991.

LABOURY, D. Akhenatón, el primer faraón Monoteísta de la Historia.

Madrid: La esfera de los libros, 2012.

LETHABY, W.R. Architecture Mysticism and Myth. Nueva York: Macmillan \& Co.

MADERUELO, J. Joachim Patinir. El paso de la laguna Estigia. Madrid:

Abada Editores, 2012.

MOOREY, P. R. S. Ancient Mesopotamian Materials and Industries: the Archeological Evidence. Oxford: Oxford University Press, 1994.

NIETO ALCAIDE, V. La luz, símbolo y sistema visual: El espacio y la luz en el arte gótico y del Renacimiento. Madrid: Ediciones Cátedra, 1978.

PIRENNE, J. Historia de la civilización del Antiguo Egipto, vol. II. Barcelona: Editorial Éxito, 1963.

RUBIO HERNÁNDEZ, R. El vidrio y sus máscaras. El sueño de la arquitectura de cristal. (Tesis doctoral inédita). Madrid: ETSAM, Universidad Politécnica de Madrid, 2006.

TAIT, H. (ed.). Five Thousand Years of Glass. Londres: British Museum Press, 1995.

WHITEHOUSE, D. Glass Short History. Londres: British Museum Press, 2012.

YARZA, J.; GUARDIA, M.; y VICENS, T. (eds.). Arte Medieval, vol. 1, Alta Edad Media y Bizancio. Barcelona: Gustavo Gili, 1982.
REFERENCES

Anonymous, La carta del Preste Juan. Madrid: Ediciones Siruela, 2004. ASSMANN J. Moisés el egipcio. Madrid: Oberón Grupo Anaya, 2003.

BARGEBUHR, F. El palacio de La Alhambra en el siglo XI. Mexico: Graduate

College, State University of Iowa, 1966.

BARGEBUHR, F. The Alhambra: A Cycle of Studies on the 11th Century in Moorish Spain. Walter de Berlín: Gruyter and Co., 1968.

BARRY, F. 'Walking on Water. Cosmic Floors in Antiquity and the Middle Ages. The Art Bulletin, 2007, 89(4). pp. 627-656.

BELTING, H. El Bosco. El jardín de las delicias. Madrid: Abada Editores, 2016.

BEN-SASSON, H. (ed.) Historia del pueblo judío. Desde los orígenes hasta la Edad Media. Madrid: Alianza Editorial, 1988.

Biblia de Jerusalén. Bilbao: Desclee De Brouwer, 1999.

BLETTER, R. H. Bruno Taut and Paul Scheerbart's Vision: Utopian Aspects of German Expressionist Architecture. (Unpublished Ph.D thesis). New York: Columbia University, 1973.

BRUYNE, E. de. La estética de la Edad Media. Madrid: Antonio Machado Libros, 2010.

CIRLOT, V. Figuras del destino. Mitos y símbolos de la Europa medieval. Madrid: Ediciones Siruela, 2005.

COLONNA, F. Sueño de Polífilo. Barcelona: Acantilado, 2008.

Corán. Barcelona: Editorial Planeta, 2014.

FRANKL, P. The Gothic: Literary Sources and Interpretations through Eight Centuries. Princeton: University Press Princeton, 1960.

FREUD, S. Moisés y la religión monoteísta. Buenos Aires: Editorial Losada, 1960.

GINZBERG, L. The Legends of the Jews. vol. IV: Bible Times and Characters from the Joshua to Esther. Philadelphia: The Jewish Publication Society of America, 1913.

GINZBERG, L. The Legends of the Jews. vol. vI: Notes to Volumes III and IV.

From Moses in the Wilderness to Esther. Philadelphia: The Jewish Publication Society of America, 1946.

HIPONA, A. Confesiones. Madrid: Espasa Calpe, 1983.

KRAUSS, R. Moïse le Pharaon. Monaco: Les Editions du Rocher, 2000.

KRAUTHEIMER, R. Arquitectura Paleocristiana y Bizantina. Madrid: Ediciones Cátedra, 2011.

KURINSKY, S. The Glass Makers: an Odyssey of the Jews. The First Three Thousand Years. New York: Hippocrene Books, 1991.

LABOURY, D. Akhenatón, el primer faraón Monoteísta de la Historia.

Madrid: La esfera de los libros, 2012.

LETHABY, W.R. Architecture Mysticism and Myth. New York: Macmillan \& Co.

MADERUELO, J. Joachim Patinir. El paso de la laguna Estigia. Madrid: Abada Editores, 2012.

MOOREY, P. R. S. Ancient Mesopotamian Materials and Industries: the Archeological Evidence. Oxford: Oxford University Press, 1994.

NIETO ALCAIDE, V. La luz, símbolo y sistema visual: El espacio y la luz en el arte gótico y del Renacimiento. Madrid: Ediciones Cátedra, 1978.

PIRENNE, J. Historia de la civilización del Antiguo Egipto, vol. II. Barcelona:

Editorial Éxito, 1963.

RUBIO HERNÁNDEZ, R. El vidrio y sus máscaras. El sueño de la arquitectura de cristal. (Unpublished Ph.D thesis). Madrid: ETSAM, Universidad Politécnica de Madrid, 2006.

TAIT, H. (Ed.). Five Thousand Years of Glass. London: British Museum Press, 1995.

WHITEHOUSE, D. Glass Short History. London: British Museum Press, 2012.

YARZA, J.; GUARDIA, M.; VICENS, T. (eds.). Arte Medieval, vol. 1, Alta Edad

Media y Bizancio. Barcelona: Gustavo Gili, 1982. 